\title{
KONSEP SEMAK DAN IMBANG MENURUT ISLAM DAN APLIKASINYA DALAM SISTEM KEHAKIMAN ISLAM DI MALAYSIA
}

\section{The Concept of 'Checks and Balances' in the Perspective of Islam and Its Application in the Islamic Judicial System in Malaysia}

\author{
Siti Rohida Asrani ${ }^{1}$ \\ Zuliza Mohd Kusrin²
}

\begin{abstract}
This article discusses the concept of 'checks and balances' in accordance with Islam and its application in the Islamic Judicial System in Malaysia. As the main objective of establishing the court is to uphold justice between disputing parties, 'checks and balances' are perceived as a mechanism in assisting our Islamic judiciary towards achieve this objective. Despite the ambiguity in understanding this concept in Islam, it has been widely used in Western nations, whether in administration or law. Yet, this does not mean that Islam does not have a specific mechanism in forming or managing a government. Islam has actually practised this concept long prior, consistent with the contents of the al-
\end{abstract}

\footnotetext{
1 Master Candidate, Department of Shariah, Faculty of Islamic Studies, The National University of Malaysia, 43600 Bangi, sitirohidaasrani87@gmail.com

2 Senior Lecturer, Department of Shariah, Faculty of Islamic Studies, The National University of Malaysia, 43600 Bangi, zulifpi@yahoo.co.uk
} 
Qur'ān and Sunnah; especially in both administrative and judicial aspects. Thus, the objective of this paper is to study the concept of 'checks and balances' in Islam. For the purpose of this study, the researcher used a qualitative research methodology involving a content analysis study through primary and secondary sources including semi-structured interviews. The finding of this study discovers that the word 'Hudüd Alläh' is widely used in Islam rather than the 'checks and balances'term which was introduced by Western legal system. The principles contained in the 'Hudüd Alläh' cover both the external and internal aspects of each individual, which later produces the most trustworthy and fair creatures of Allah in every aspects of their lives. This would then be the differentiation between the 'Hudüd Alläh' and the concept of 'checks and balances', in which the 'checks and balances' concept only focuses on the external aspects of governance.

Keywords: 'checks and balances', Islamic Judicial System, Malaysia

\section{PENDAHULUAN}

Ungkapan semak dan imbang boleh dikatakan sebagai istilah yang jarang digunakan dalam Islam. Namun begitu, ini tidak bermaksud istilah ini tidak ada di dalam Islam. Secara umumnya, semak dan imbang adalah salah satu daripada ciri-ciri dalam pengamalan doktrin pengasingan kuasa yang diperkenalkan oleh Barat yang membenarkan pertindanan bidang kuasa antara antara tiga badan utama dalam pemerintahan sesebuah kerajaan iaitu badan eksekutif, badan perundangan dan badan kehakiman. Sistem ini memberikan hak dan kuasa yang terkawal kepada setiap badan tersebut bagi memastikan sama ada badan-badan lain menjalankan kuasanya menurut perlembagaan atau sebaliknya.

Oleh itu, artikel ini akan membincangkan konsep semak dan imbang menurut Islam dan aplikasinya dalam sistem kehakiman Islam di Malaysia. Oleh kerana konsep ini telah dibincangkan secara meluas di Barat, maka penulis akan menerangkan secara ringkas tentang konsep ini menurut perspektif Barat. Menurut pandangan sarjana Barat, matlamat utama semak dan imbang ini bagi memberikan setiap badan haknya dan badan lain tidak boleh untuk mencampurinya tanpa sebab dan alasan yang kukuh. ${ }^{3}$ Seterusnya, artikel ini

3 Encyclopedia America, vol. 6 (Danbury: Sholastic Library Publishing, 2006), 353. 
akan menghuraikan konsep semak dan imbang menurut perspektif Islam dan mekanisme yang diaplikasikan dalam sistem kehakiman Islam di Malaysia.

\section{KONSEP SEMAK DAN IMBANG MENURUT PERSPEKTIF BARAT}

Hingga ke hari ini, tidak ada suatu pendapat yang jelas mengenai kemunculan istilah 'checks and balances' ini. Namun terdapat beberapa kenyataan yang telah menjurus ke arah istilah 'checks and balances'. Konsep semak dalam perlembagaan muncul hasil daripada cabang dalam teori klasik berkenaan pembahagian kuasa antara tiga badan utama iaitu badan perundangan, badan eksekutif dan badan kehakiman. Pembahagian kuasa ini dapat membezakan kuasa antara tiga badan tersebut. Setelah itu, wujud pembangunan semak dan imbang dengan tujuan untuk memastikan bahawa kuasa kerajaan tidak akan digunakan secara kasar dan melampaui batas yang ditetapkan. Namun begitu, dalam bentuk asalnya konsep yang terlibat berkenaan dengan kelas-kelas sosial daripada jabatan kerajaan. ${ }^{4}$

Antara kenyataan yang menggunakan istilah 'checks and balances' terdapat dalam beberapa penulisan, contohnya Nedham telah menulis mengenai balance or check pada tahun $1654 .^{5}$ Manakala Toland pula menggunakan ungkapan check and balance pada tahun 1701. Seterusnya ialah Gouverneur Morris juga dalam penulisannya menyentuh mengenai terma semak dan imbang dalam ungkapannya every check and balance pada tahun 1776. Namun begitu, pendapat yang kuat mengatakan terma semak dan imbang mula diperkenalkan oleh John Adams pada tahun 1787 dalam ucapan pembukaan Defense of the Constitutions of the United States. ${ }^{6}$

Dari segi makna semak dan imbang itu sendiri terdapat pelbagai tafsiran yang diguna pakai. Pada dasarnya 'checks and balances' merupakan satu prinsip pemerintahan di mana cawangan atau cabang berasingan dikuasakan untuk mengelakkan tindakan oleh cabang lain dan di dorong atau digalakkan untuk berkongsi kuasa. Semak dan imbang selalu diguna pakai atau diterapkan terutama dalam pemerintahan berperlembagaan. Prinsip ini merupakan

$4 \quad$ Encyclopedia America, 353.

5 David Wootton, 'Liberty, Metaphor, and Mechanism: Checks and Balances and the Origins of Modern Constitutionalism - Liberty and American Experience in the Eighteenth Century,' http://oll.libertyfund.org/?option=com_staticxt\&staticfile. September 2011.

6 David Wootton, 'Liberty, Metaphor, and Mechanism: Checks and Balances and the Origins of Modern Constitutionalism - Liberty and American Experience in the Eighteenth Century.' 
satu asas yang cukup penting dalam tiga bahagian utama dalam kerajaan sepertimana yang terdapat di Amerika Syarikat yang membahagikan kuasa antara tiga badan utama iaitu badan perundangan, badan eksekutif dan badan kehakiman. $^{7}$

Selain itu, 'checks and balances' juga boleh dikatakan satu kawalan perlembagaan di mana setiap cabang dalam kerajaan terpisah dan ianya telah menyekat kuasa antara satu sama lain sehingga tidak ada satu antara mereka menjadi cabang yang tertinggi. Antara negara yang mengamalkan sistem 'checks and balances' ini secara menyeluruh adalah negara Amerika Syarikat berdasarkan peruntukan dalam Perlembagaannya. Kebanyakan negara, negeri dan kerajaan tempatan mempunyai sistem 'checks and balances' termasuklah negara yang mengamalkan pemerintahan diktator yang digunakan untuk melengkapkan jaminan terhadap kerajaan di samping mengukuhkan tanggungjawab. ${ }^{8}$

Di samping itu, 'checks and balances' juga boleh diertikan sebagai kuasakuasa tertentu dalam salah satu cabang kerajaan yang membenarkan untuk menghadkan kuasa cabang yang lain. ${ }^{9}$ Blackstone menjelaskan mengenai sistem semak dan imbang sebagaimana berikut: ${ }^{10}$

"....In the legislature, the people are a check upon the nobility, and the nobility a check upon the people; by the mutual privilege of rejecting what the other has resolved: while the king is a check upon both, which preferves the executive power from encroachment. And this very executive power is again checked and kept within due bounds by the two houses, thourgh the privilege they have of inquiring into, impeaching, and punishing the conduct (not indeed of the king, which would destroy his constitutional independence; but, which is more beneficial to the public) of his evil and prenicious counsellor. Thus every branch of our civil polity supports and is supported, regulates and is regulated, by the rest; for the two houses naturally drawing in two directions of opposite interest, and the prerogative in another still different from them both, they mutually keep each other from exceeding their proper limits while the whole is prevented from separation, and artificially connected together by the mixed

The New Encyclopedia Britannica, vol. 3 (International Copyright Union, 1995), 146.

8 Encyclopedia America, 353.

9 Daniel E. Branmen Jr \& Lawrence W. Baker, Checks and Balances: The Three Branches of the America Government (Detroit: Thomson/Gale, 2005), 2.

10 William Blackstone, Commentaries on the Laws of England, $15^{\text {th }}$ ed. (London: A. Strahan, 1809), 154-155. 
nature of the crown, which is a part of the legislative, and the sole executive magistrate. Like three distinct powers in mechanics, they jointly impel the machine of government in a direction different from what either, acting by itself, would have done; but at the same time, in a direction partaking of each, and formed out of all: a direction which constitutes the true line of the liberty and happiness of the community..."

Secara ringkas, Blackstone mengatakan bahawa dalam perundangan, rakyat merupakan penyemak ke atas golongan bangsawan dan bangsawan merupakan penyemak ke atas rakyat. Sementara raja pula penyemak bagi kedua-duanya. Setiap cawangan menyokong dan disokong, mengawal dan dikawal. Setiap mereka mempunyai hak atau keistimewaan dan saling menjaga hak antara satu sama lain dari melebihi batas yang telah ditentukan. Tiga kuasa yang berbeza iaitu rakyat, bangsawan dan eksekutif bersama-sama menggerakkan sistem kerajaan walaupun mempunyai arah atau matlamat yang berbeza. Akhirnya matlamat ini akan membentuk satu garis sebenar kebebasan dan kebahagian masyarakat. Sebenarnya apa yang cuba disampaikan oleh Blackstone ini merupakan suatu kaedah atau prinsip yang cuba dilaksanakan dan dipraktikkan dalam pentadbiran sesebuah negara. Wujudnya mekanisme ini secara tidak langsung memberi jaminan akan wujudnya keadilan dalam setiap organisasi mahupun komuniti dalam sesebuah masyarakat.

Walau bagaimanapun, tidak banyak tafsiran atau definisi yang secara khusus menyentuh berkaitan konsep ini. Ini menunjukkan seolah-olah konsep dan mekanisme ini tidak perlu dibahaskan kerana ungkapan itu sendiri dianggap sudah jelas dan tidak perlu diperincikan dengan lebih lanjut. Walau apapun konsep semak dan imbang ini secara automatis membayangkan betapa sesuatu kuasa itu perlu diimbangi oleh agensi atau institusi yang lain supaya pemegang kuasa tidak berada di dalam keadaan monopoli. Ini dengan sendirinya mengisyaratkan kepada kita betapa semak dan imbang adalah suatu bentuk kawalan ke atas kuasa-kuasa yang sah. Ia dapat mengelakkan orang yang mempunyai kuasa yang sah supaya tidak salah dalam menggunakan kuasanya iaitu ia tidak menyimpang atau bertentangan dengan maksud asal mengapa kuasa itu diberikan kepadanya. ${ }^{11}$

Oleh itu, mekanisme ini amat penting dalam mentadbir dan menguruskan sesebuah kerajaan. Namun begitu daripada segi prosedurnya ia berbeza mengikut sesebuah negara. Ini kerana terdapatnya perbezaan dari segi pentadbiran iaitu adanya sesebuah negara yang mengamalkan sisten berpresiden

11 Abdul Aziz Bari, Perlembagaan Malaysia Teoti \& Praktis (Selangor: Arah Publications, 2008), 63. 
dan juga sistem demokrasi berparlimen. Corak pemerintahan yang berbeza akan menghasilkan prosedur mekanisme yang berbeza namun matlamat yang dihasilkan daripada mekanisme ini adalah sama iaitu tidak berlakunya monopoli oleh pemegang kuasa yang telah diberi kuasa. Mekanisme ini secara umumnya adalah tidak tetap bentuknya kerana ia berubah mengikut keadaan dan kehendak semasa.

United Kingdom antara negara kuasa besar yang digeruni suatu ketika dulu. Mekanisme semak dan imbang bermula di negara ini adalah dengan bermulanya revolusi 1688 yang melahirkan persetujuan iaitu kuasa memerintah dikongsi oleh Raja dan Parlimen. Dengan persetujuan itu undang-undang boleh dibuat, dipinda atau dimansuhkan melalui parlimen yang terdiri daripada House of Lords dan House of Commons. Proses tersebut perlu dibuat melalui Akta Parlimen. Persetujuan itu juga boleh menjamin kebebasan para hakim tetapi mereka tidak boleh mempersoalkan sama ada undang-undang yang diluluskan oleh parlimen itu sah atau sebaliknya. Namun begitu, situasi ini telah berubah kerana mekanisme ini telah mempunyai beberapa tahap dan berbeza dengan apa yang telah wujud pada 1688. Para hakim sudah boleh mempersoalkan keputusan menteri (eksekutif). Ini disebabkan oleh kemasukan Britain ke dalam Kesatuan Eropah (EU) menyebabkan peranan kehakiman semakin besar dengan wujudnya triti kesatuan. ${ }^{12}$

Walaupun mekanisme semak dan imbang ini mula mengalami kemerosotan namun mekanisme ini masih wujud. Contohnya dalam hubungan antara parlimen dan kabinet atau kerajaan yang memerintah, terdapat beberapa mekanisme yang boleh dilakukan antaranya usul undi tidak percaya yang boleh memaksa seseorang Perdana Menteri atau anggota kabinetnya meletakkan jawatan. Mahkamah pula, melalui doktrin ultra vires dalam semakan kehakiman boleh menyekat penyalahgunaan kuasa oleh kerajaan. Sementara itu para hakim, meskipun kebebasan dan jawatan mereka dilindungi, tidak kebal daripada dibuang kerja dengan syarat ia dilakukan mengikut prosedur yang ditetapkan. Dengan kata lain tiap-tiap cabang baik dewan perundangan, badan kehakiman dan eksekutif tidak boleh lari dari pertanggungjawaban dan ditamatkan kewujudannya. ${ }^{13}$

Berlainan pula dengan mekanisme semak dan imbang yang berlaku di Amerika Syarikat. Perlembagaan Amerika Syarikat ditulis pada tahun 1787. Secara amnya pentadbiran di Amerika Syarikat terbahagi kepada tiga badan utama iaitu perundangan, eksekutif, dan kehakiman. Ketiga-tiga badan ini tidak bebas dari satu sama lain kerana Perlembagaan menubuhkan satu sistem

\footnotetext{
12 Abdul Aziz Bari, Perlembagaan Malaysia Teori \& Praktis, 64.

13 K. Ramanatahan, Asas Sains Politik (Shah Alam: Fajar Bakti, 2003), 307.
} 
semak dan imbang untuk membantu memastikan bahawa tiada salah satu badan menjadi terlalu berkuasa. Setiap badan mempunyai kuasa yang boleh digunakan untuk menyemak dan mengimbangi operasi dan kuasa kedua-dua badan yang lain. ${ }^{14}$

Walaupun Presiden adalah berkuasa veto dalam rang undang-undang yang diluluskan oleh Kongres, pihak Kongres boleh membatalkan veto tersebut. Dalam kuasa pelantikan pula, meskipun Presiden diberi kuasa melantik para hakim, ia perlu diluluskan oleh Senat. Di samping itu, sebarang perjanjian antarabangsa juga perlu kepada sokongan dua pertiga undi daripada anggota Senat. Contohnya Presiden Woodrow Wilson (1912-1920) telah membuat perjanjian yang wujudkan Liga Bangsa-Bangsa tanpa persetujuan Senat. Oleh itu, Senat menolaknya dan tindakan Senat ini telah menghalang penglibatan Amerika Syarikat dalam pertubuhan antarabangsa tersebut. Selain itu, Presiden boleh dibuang atau digugurkan melalui proses 'impeachment' oleh Kongres. Mahkamah pula boleh menyemak segala tindakan eksekutif dan badan perundangan bagi menentukan bahawa kesemuanya dibuat dalam batasan yang telah ditetapkan oleh perlembagaan. ${ }^{15}$

Penulis mengemukakan dua contoh negara yang mengamalkan mekanisme semak dan imbang dalam pentadbiran mereka. Britain dan Amerika Syarikat adalah antara negara yang sangat berpengaruh dan sistem pentadbiran mereka sentiasa menjadi perhatian negara-negara yang lain. Pengukuhan sistem pentadbiran yang lebih teratur dan sistematik akan membawa kemajuan dan kestabilan dalam negara. Setiap agensi atau organisasi perlu menggunakan kuasa yang telah ditentukan tanpa melampaui batasan yang telah ditetapkan.

Kesimpulannya, sistem 'checks and balances' merupakan satu kaedah bagi mengehadkan kuasa sesuatu badan atau cabang dalam sesebuah negara di samping wujud kawalan antara tiga badan utama dalam sesebuah kerajaan iaitu badan perundangan, badan eksekutif dan badan kehakiman. Ini adalah tujuan utama sistem ini diperkenalkan. Sistem ini jelas memperlihatkan bahawa setiap badan mempunyai tanggungjawab masing-masing dan tidak boleh mencampuri urusan badan lain. Kawalan kuasa setiap badan utama dalam sesebuah pentadbiran amat penting dan perlu diwujudkan untuk mengimbangi kuasa setiap badan yang terlibat. Ini kerana, kawalan kuasa yang seimbang akan memberi impak yang sangat baik dalam sesebuah negara. Begitu juga, sekiranya terdapat lebihan kuasa dalam sesuatu badan akan mendatangkan

14 Martin Kelley, 'Checks and Balances in the U.S. Government,' http:// americanhistory.about.com/od/usconstitution/a/checks_balances.htm14/12/12., diakses pada 18 Jun 2013.

15 K. Ramanatahan, Asas Sains Politik, 297. 
kesan yang buruk dalam pentadbiran sesebuah negara. Perkara ini perlu diambil perhatian yang sangat serius bagi memastikan supaya kebebasan setiap badan tidak tergugat dan terancam.

\section{KONSEP SEMAK DAN IMBANG MENURUT PERSPEKTIF ISLAM}

Secara dasarnya, Islam dan Barat adalah berbeza dari segi sumber utama sebagai rujukan dalam pemerintahan dan pentadbiran. Di Barat, perlembagaan adalah rujukan tertinggi manakala dalam Islam, al-Quran adalah sebagai sumber rujukan utama dalam pelbagai keadaan. Sebagaimana firman Allah SWT:

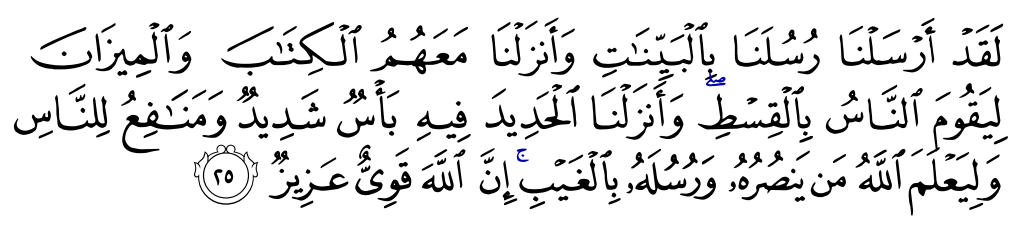

"Demi sesungguhnya! Kami telah mengutus Rasul-Rasul Kami Dengan membawa bukti-bukti dan mukjizat yang jelas nyata, dan Kami telah menurunkan bersama-sama mereka Kitab Suci dan keterangan yang menjadi neraca keadilan, supaya manusia dapat menjalankan keadilan dan Kami telah menciptakan besi dengan keadaannya mengandungi kekuatan yang handal serta berbagai faedah lagi bagi manusia. (Dijadikan besi dengan keadaan yang demikian, supaya manusia menggunakan faedahfaedah itu dalam kehidupan mereka sehari-hari) dan supaya ternyata pengetahuan Allah tentang orang yang (menggunakan kekuatan handalnya itu untuk) menegak dan mempertahankan agama Allah serta menolong Rasul-rasulNya, padahal balasan baiknya tidak kelihatan (kepadanya); Sesungguhnya Allah Maha Kuat lagi Maha Kuasa."

(Surah al-Hadīd, 57: 25)

Ayat di atas jelas menunjukkan bahawa Allah SWT mengutuskan para Rasul yang membawa Kitab Suci (al-Quran) sebagai neraca keadilan iaitu sebagai petunjuk kepada manusia dalam menjalani kehidupan seharian. Al-Quran diletakkan di tempat yang tertinggi supaya manusia sentiasa menjadikannya sebagai rujukan utama dalam apa-apa perkara yang ingin dilakukan. Al-Quran juga telah meletakkan garis panduan yang jelas berkaitan dengan semua aspek kehidupan manusia sama ada berkaitan perundangan, muamalah, akhlak, 
akidah dan lain-lain. Oleh itu, amat rugi bagi sesiapa yang membelakangkan al-Quran dalam kehidupan sehariannya.

Berkenaan istilah semak dan imbang dalam Islam tidak dinyatakan dengan jelas. Namun begitu, terdapat seorang tokoh gerakan Islam iaitu al-Maududi ${ }^{16}$ yang telah menggunakan terma Divine Limits iaitu Hudud Allah. Konsep terma ini amat berbeza dengan sistem yang diperkenalkan di Barat iaitu 'checks and balances' yang menjadi suatu sistem dalam pentadbiran mereka. Menurut alMaududi, terma ini mengandungi prinsip-prinsip tertentu yang menjadi batasan kehidupan manusia. Melalui batasan-batasan inilah, perbuatan manusia tidak akan melampauinya dan mengikut prinsip yang telah ditetapkan. Prinsipprinsip yang wujud ini akan memandu manusia ke arah jalan yang benar serta adil dalam setiap tindakan yang dilakukan.

Terdapat beberapa dalil al-Quran yang berkaitan dengan Hudud Allah SWT yang menjadi satu panduan atau mekanisme dalam menentukan sesuatu hukum. Batasan-batasan dan aturan-aturan Allah SWT yang telah wujud sekian lama di dalam al-Quran menunjukkan bahawa terma semak dan imbang ini telah lama dijalankan antaranya firman Allah SWT:

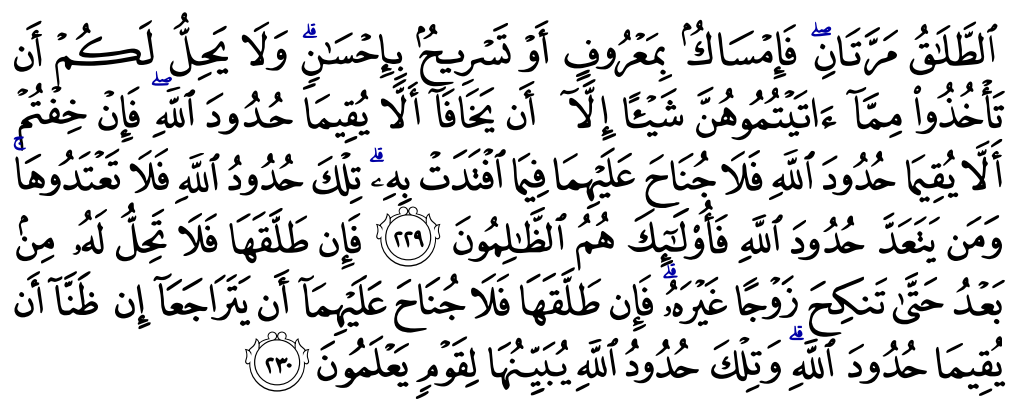

"Talak (yang boleh dirujuk kembali itu hanya) dua kali. Sesudah itu bolehlah ia (rujuk dan) memegang terus (isterinya itu) dengan cara yang sepatutnya atau melepaskan (menceraikannya) dengan cara yang baik dan tidaklah halal bagi kamu mengambil balik sesuatu dari apa yang telah kamu berikan kepada mereka (isteri-isteri yang diceraikan itu) kecuali jika keduanya (suami isteri) takut tidak dapat menegakkan aturan-aturan hukum Allah. Oleh itu kalau kamu khuatir bahawa kedua-duanya tidak dapat menegakkan aturan-aturan hukum Allah, maka tidaklah mereka berdosa - mengenai bayaran (tebus talak) yang diberikan oleh

16 Abu A'la Al-Maududi, Islamis Law and Its Constitution (Lahore: Islamic Publication, 1980), 142. 
isteri untuk menebus dirinya (dan mengenai pengambilan suami akan bayaran itu). Itulah aturan-aturan hukum Allah maka janganlah kamu melanggarnya; dan sesiapa yang melanggar aturan-aturan hukum Allah, maka mereka itulah orang-orang yang zalim. Sesudah (diceraikan dua kali), itu jika diceraikan pula (bagi kali yang ketiga) maka perempuan itu tidak halal lagi baginya sesudah itu, sehingga ia berkahwin dengan suami yang lain. Setelah itu kalau ia diceraikan (oleh suami baharu itu dan habis idahnya), maka mereka berdua (suami lama dan bekas isterinya) tidaklah berdosa untuk kembali (maskahwin semula), jika mereka kuat menyangka akan dapat menegakkan aturan-aturan hukum Allah dan itulah aturan-aturan hukum Allah, diterangkanNya kepada kaum yang (mahu) mengetahui dan memahaminya..." 17

(Surah al-Baqarah, 2: 229-230)

Berdasarkan dua ayat di atas, terdapat enam perkataan yang berkaitan Hudud Allah. Pengulangan ini memberi maksud bahawa terdapat penegasan terhadap hukum-hukum Allah. Menurut Ibn Kathīr ayat ini berkaitan dengan bilangan talak yang boleh dirujuk. Ayat Hudud Allah dalam ayat di atas memberi maksud bahawa Allah SWT telah membatasi para suami untuk menceraikan isterinya dengan tiga talak sahaja. Ini berbeza dengan talak yang digunapakai oleh tradisi masyarakat yang berlaku pada permulaan Islam yang tiada had talak. Oleh itu, di penghujung ayat 229 menjadi penguat kepada Hudud Allah yang meliputi syariat-syariat yang telah ditetapkan oleh Allah SWT untuk mereka supaya menjadi batasan dari melakukan kezaliman dan supaya tidak melanggar perintahNya. ${ }^{18}$ Begitulah juga maksud Hudud Allah bagi ayat 230 yang membawa maksud batasan-batasan hukum Allah SWT menurut Ibn Kathir. Ini bermaksud segala syariat yang diturunkan oleh Allah SWT mempunyai batasan-batasan tertentu supaya setiap Muslim tidak melanggarnya. Perlunya batsan-batasan ini supaya setiap Muslim menjaga tingkah laku mereka setiap masa dalam melakukan sesuatu perbuatan.

Manakala menurut Sayyid Qutb pula perkataan Hudud Allah ini mempunyai sedikit perkaitan dengan ayat Hudud Allah dalam surah yang sama iaitu surah al-Baqarah ayat ke 187 yang juga menyentuh mengenai Hudud Allah. Dalam ayat itu mereka diberi amaran berbentuk larangan supaya "jangan mendekati"

17 Semua terjemahan ayat al-Quran dalam tulisan ini berdasarkan kepada Tafsir Pimpinan al-Quran kepada Pengertian al-Quran, edisi ke-8 (Kuala Lumpur: Bahagian Hal Ehwal Islam, Jabatan Perdana Menteri, 1987).

18 Ibn Kathīr, Imam Jalil Hafiz al-Dīn Abū Fidā' Ismā‘̄il, Tafsīr Ibn Kathīr, vol. 1 (Qāhirah: Maktabah Qayyimah,1993), 257-263. 
manakala ayat kedua iaitu ayat 229 surah al-Baqarah juga pula diberi amaran supaya "jangan melanggarnya". Walaupun terdapat sedikit perbezaan maksud di situ, secara keseluruhannya ia membawa maksud bahawa sekiranya batasanbatasan hukum ini dilanggar maka ia membawa kesan yang tidak baik antara kedua-dua pihak. ${ }^{19}$

Bagi ayat 230 pula, Sayyid Qutb menjelaskan Hudud Allah di situ bukanlah berkaitan persoalan mengikut nafsu dan mengikuti kehendak mereka malah ia adalah persoalan menegakkan batas-batas atau peraturan-peraturan Allah SWT dan itulah garis-garis sempadan lingkungan hidup. Menurut beliau lagi, sekiranya hidup itu melampaui batas garis sempadan ini, maka ia bukanlah lagi bentuk hidup yang dikehendaki dan diredhai oleh Allah SWT. Antara bukti rahmat Allah SWT terhadap para hamba-Nya ialah Dia tidak tinggalkan batas-batas peraturan-Nya dalam keadaan kabur dan majhül malah semua batas-batas itu dijelaskan di dalam al-Quran iaitu dijelaskan kepada golongan manusia yang mengetahui. Orang-orang yang benar-benar mengetahui itulah orang-orang yang mengerti batas-batas dan peraturan-peraturan Allah SWT dan berhenti di garis sempadannya. Jika tidak, maka beliau menegaskan bahawa itulah kejahilan yang keji dan jahiliyyah yang buta.

Al-Marāghī pula menyatakan ayat Hudud Allah pada ayat 229 itu yang memberi makna tidak dapat menegakkan itu ialah tidak dapat menjaga dengan baik. Hukum-hukum Allah SWT ertinya peraturan Allah SWT yang berkaitan dengan pergaulan suami isteri, persamaan dan hak kewajipan mereka, kekuasaan suami ke atas isteri, kerjasama melaksanakan pengurusan rumah tangga, pendidikan anak-anak untuk kebaikan agama dan dunia mereka tanpa melakukan perbuatan yang saling memudaratkan seperti yang dinyatakan oleh firman Allah SWT:

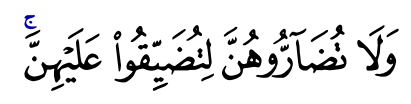

“....Dan janganlah kamu adakan sesuatu yang menyakiti mereka (di tempat tinggal itu) dengan tujuan hendak menyusahkan kedudukan mereka (supaya mereka keluar meninggalkan tempat itu).."

(Surah al-Ṭalāq, 65:6)

19 Sayyid Qutb, Tafsīr fì Zilāl al-Qur'ān, vol. 1 (Beirūt: Dār Syuruk, 1972), 250252. 
Jika suami isteri bimbang akan berlakunya pelanggaran hukum Allah SWT, maka pemerintah adalah pihak pertama yang dituntut untuk menegakkan kemaslahatan manakala para hakim dan seluruh anggota masyarakat menjadi pengawasnya. Perintah dan larangan yang telah dinyatakan dalam ayat tersebut adalah hukum Allah SWT yang diatur untuk kepentingan suami isteri. Oleh itu, setiap pasangan suami isteri hendaklah menjauhi perkara yang telah diharamkan oleh Allah SWT supaya kemurkaan Allah SWT tidak tertimpa ke atas mereka. ${ }^{20}$

Bagi ayat 230 pula, al-Marāghī dalam tafsirannya menyebut berkaitan Hudud Allah ini apabila mereka menyakini bahawa mereka akan dapat melaksanakan kewajipan dan hak antara satu sama lain menurut ketentuan Allah SWT akan tetapi seandainya mereka bimbang akan berlaku kederhakaan (nusyuz) daripada pihak isteri atau perbuatan mudarat daripada suami, pasti tindakan ruju' kembali sebegini dilaknat oleh Allah walaupun ia adalah sah menurut Islam.

Hukum yang dijelaskan oleh Allah SWT melalui rasul-Nya dalam alQuran ini adalah untuk orang yang memahami kegunaannya dan memahami kemaslahatannya supaya mereka mengetahui sesuai dengan apa yang menjadi tuntutan, faedah dan manfaat. Sebaliknya ia bukan ditujukan kepada orang yang bodoh tentang perkara tersebut kerana mereka tidak mempunyai niat yang baik dan rasa ikhlas untuk meruju' isterinya. Sebaliknya ia meruju' sekadar untuk melempiaskan niat jahat dan membalas dendam.

Kesimpulannya, ayat al-Quran di atas jelas menunjukkan bahawa batasbatas hukum Allah SWT hendaklah dijaga dengan sebaiknya. Pelanggaran terhadap batas-batas hukum ini akan mendatangkan kemurkaan daripada Allah SWT. Ini adalah Hudud Allah atau semak dan imbang yang terbaik yang perlu kita ikuti dan contohi. Berdasarkan kepada prinsip-prinsip yang telah diperkenalkan oleh al-Maududi ini, penulis mendapati terdapat dua perkara yang penting yang terhasil iaitu mekanisme dalaman dan luaran. Berdasarkan kepada semakan dalaman dan luaran, amat jelaslah bahawa semakan dalaman sangat memainkan peranan yang penting dalam pembentukan peribadi seseorang individu. Semakan dalaman yang baik akan menghasilkan seorang individu Muslim yang kuat pegangannya kepada Allah SWT. Islam telah meletakkan garis panduan yang jelas terhadap setiap individu Muslim. Tiga elemen utama iaitu Iman, Islam dan Ihsan yang menjadi tunjang kehidupan setiap individu Muslim. Ketiga-tiga elemen ini akan menjadi penanda aras kelakuan yang dilakukan oleh seseorang Muslim. Oleh itu, setiap perbuatan

20 Al-Marāghī, Aḥmad Mușțafā, Tafs̄ìr al-Marāghī, vol. 1 (Beirūt: Dār al-Kutub 'Alamiyyah, 1974), 169-176. 
yang dilakukan akan dipertanggungjawab di akhirat. Setiap perbuatan akan dinilai dan diukur bagi memastikan seseorang muslim itu tidak melanggar perintah dan larangan Allah SWT. Dengan adanya elemen ini akan dapat melahirkan seorang yang insan kamil.

Islam adalah agama Allah SWT yang diwahyukan kepada Rasulullah SAW dan ia adalah agama yang berpaksikan kepada keimanan dan perbuatan (amal). Keimanan itu pula merupakan akidah dan pokok yang di atasnya berdiri syariat. Iman adalah kepercayaan kepada makrifat Allah SWT sama ada nama-namaNya atau sifat-sifatNya. ${ }^{21}$

Rukun Iman terdiri daripada kepercayaan kepada Allah SWT, malaikat, Rasulullah, kitab, hari kiamat dan qada dan qadar menjadi benteng utama dalam diri seseorang muslim. Manakala rukun Islam yang lima iaitu mengucap syahadah, mendirikan solat, menunaikan zakat, berpuasa dan menunaikan haji antara amalan yang terhasil daripada keimanan kepada Allah SWT. Ihsan pula ialah anjuran untuk melakukan kebaikan dan meninggalkan larangan. Melalui Ihsan inilah keikhlasan untuk melakukan kebaikan akan tercapai. Ihsan bermaksud kamu beribadat kepada Allah seolah-olah kamu melihatNya, walaupun kamu tidak melihat-Nya, akan tetapi Allah melihat kamu. Ringkasnya di sini bahawa Ihsan adalah melakukan sesuatu ibadat dengan baik dan tepat sepertimana yang telah diperintahkan oleh Allah SWT.

Selain daripada wujudnya ketiga-tiga elemen di atas, Islam juga menganjurkan beberapa prinsip sebagai penguat dan pengukuh dalam sistem pemerintahan dan pentadbiran. Kewujudan prinsip ini memainkan peranan yang sangat penting dalam membentuk sebuah negara yang kuat dan kukuh serta keadilan dapat dilaksanakan dengan seadilnya. Antara prinsip yang diketengahkan dan digunapakai ialah:

\section{Wilāyah al-Hisbah}

Islam memerintahkan agar setiap kemungkaran itu dihapuskan, kebaikan ditegakkan dan dalam melaksanakan perintah tersebut menjadi kewajipan kepada setiap anggota masyarakat. Ia merupakan fardu kifayah. Oleh sebab tugas ini berat dan besar dan memerlukan perhatian yang sepenuhnya terhadap pelaksanaan perintah tersebut maka dilantik muhtasib dan institusi yang mentadbirkannya dinamakan hisbah. Institusi hisbah ini merupakan sebuah institusi yang pernah memainkan peranan penting dalam negara Islam sedikit

${ }_{21}$ Sayyid Sābiq, 'Aqīdah al-Islāmiyyah (Qāhirah: al-Fatḥ al-I'lāmī al-'Arābī, 2000), 9. 
masa dahulu. Ia ialah institusi yang menjaga dan mengawasi kemaslahatan umum masyarakat Islam termasuk kegiatan politik, sosial dan ekonomi.

Hisbah dari segi bahasa bermakna ihtisab iaitu meneliti, mentadbir, melihat, mencegah atau menahan seperti mencegah seseorang daripada melakukan kemungkaran, atau mendapat balasan, seperti seseorang yang melakukan kebaikan untuk mendapat balasan (hisbah) daripada Allah SWT. ${ }^{22}$

Dari segi istilah hisbah ialah suatu gesaan ke arah melakukan kebaikan, apabila ternyata ia diabaikan dan melarang dari perbuatan mungkar, apabila ternyata ia ketara dilakukan. ${ }^{23}$ Ini bersesuian dengan firman Allah SWT:

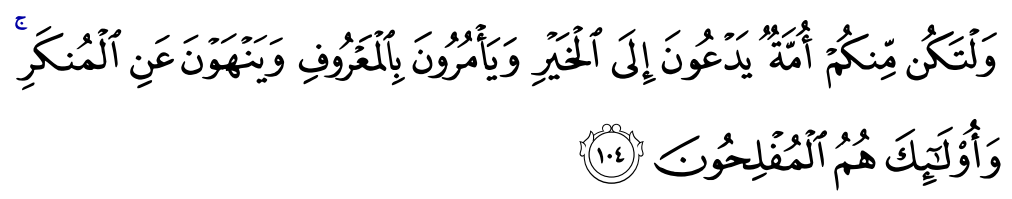

"Dan hendaklah ada di antara kamu satu puak yang menyeru (berdakwah) kepada kebajikan (mengembangkan Islam), dan menyuruh berbuat segala perkara yang baik, serta melarang daripada segala yang salah (buruk dan keji). Dan mereka yang bersifat demikian ialah orang-orang yang berjaya."

(Surah Āli 'Imrān, 3: 104)

Amalan hisbah telah lahir dan berkembang semenjak zaman awal kemunculan Islam itu lagi iaitu pada zaman Rasulullah SAW atau lebih tepat ketika tertubuhnya kerajaan Islam di Madinah. Pada waktu tersebut, gelaran untuk mereka yang menjalankan hisbah ialah petugas pasar (al-amil 'ala al$s \bar{u} q)$ atau penyelia pasar (șạhib al-sūq) yang bertanggungjawab menyelia dan mengawasi perjalanan perniagaan dan menentukan timbangan dan sukatan dalam urusniaga. Sebagai contoh, Rasulullah SAW telah melantik Sa'id bin Sa'id bin al-'As sebagai penyelia pasar di kota Mekah, sementara di kota Madinah pula beliau telah melantik Saidina 'Umar al-Khaț̣āb. ${ }^{24}$

Berdasarkan contoh-contoh yang telah berlaku sejak zaman Rasulullah SAW menunjukkan bahawa hisbah merupakan suatu institusi yang menegakkan

\footnotetext{
22 'Abd al-Karīm Zaydān, Niẓām al-Qaḍā' fì al-Syarī'ah al-Islāmiyyah (Beirūt: Muassasah al-Risālah, 1995), 111.

23 Al-Mawardī, Ab̄̄ Hasan 'Alī, al-Aḥkām Sulțāniyyah wa Wilāyah al-Dīniyyah (Beirūt: Dār al-Kutub 'Alamiyah, 1980), 299.

24 Ahmad Shalaby, Tarikh Niẓ̄m al-Qaḍa 'iyyah fí al-Islām (Azhar: Dār al-Wafā' li al-Țaba'ah, 1981), 235.
} 
makruf dan mencegah kemungkaran. Ini bersesuaian dengan firman Allah SWT yang telah ditegaskan seperti di atas. Konsep ini sama seperti yang terdapat dalam al-Quran yang menekankan konsep Hudud Allah SWT. Sesiapa yang telah melanggar batasan-batasan hukum yang telah ditetapkan akan mendapat hukuman yang setimpal. Melalui hisbah ini, muhtasib perlu turun padang untuk melihat apa-apa yang berlaku di sekitarnya bahkan orang awam juga boleh membuat aduan jika berlaku penindasan mahupun kezaliman. Maka berlakulah proses semak dan imbang supaya keadilan dapat dicapai dan memberikan kepuasan kepada pihak-pihak.

Ketika zaman pemerintahan Khalifah 'Umar, beliau sendiri yang mengetuai hisbah dengan melakukan pemeriksaan barang makanan, manisan, roti, buahbuahan, timbangan, sukatan dan sebagainya di pasar agar tidak berlaku penipuan. Pernah berlaku suatu peristiwa iaitu Khalifah 'Umar mencurahkan susu ke tanah kerana adanya penipuan dengan mencampurkan susu dengan cecair lain. Selain itu, Khalifah 'Umar juga pernah membakar rumah Rashid al-Thaqafi kerana didapati rumah tersebut ada menjual arak. ${ }^{25}$

Selain itu, seseorang yang ingin menjadi seorang muhtasib perlu memiliki beberapa ciri iaitu muhtasib hendaklah melaksanakan tugas berasaskan pengetahuan, perbuatan dan tingkahlaku muhtasib hendaklah tidak bertentangan dengan tugas dan tanggungjawab mereka. Mereka juga tidak boleh bertindak terburu-buru tanpa usul periksa dan juga tidak menghukum dengan tergesa-gesa. Semestinya niat mereka dalam tindakan adalah kerana Allah SWT semata-mata tanpa menghiraukan kemarahan atau kebencian manusia kepadanya, muhtasib hendaklah berakhlak mulia, bersopan santun, menghilangkan sifat terkeji, sabar dan tutur kata yang baik. Muhtasib juga hendaklah cekal dan tabah, berlapang dada apabila menghadapi cemuhan dan kesulitan serta menunaikan tuntutan syarak yang wajib dan sunat. Oleh itu, mereka akan disegani dan digeruni dan kata-kata mudah diterima. ${ }^{26}$

Manakala syarat seseorang itu boleh menjadi muhtasib ialah mukallaf. Maka seseorang yang tidak mukallaf tidak diwajibkan ia menyuruh dan tidak ada beban syara'. Mukallaf dalam istilah fuqaha' ialah seorang yang telah baligh dan berakal. Ayat ini sebenarnya tiada terus kepada Muslim. Ini bertujuan untuk memperkuatkan agama, menegakkan makruf dan mencegah kemungkaran, sedangkan orang bukan Islam tidak berusaha kearah memperkuatkan Islam kerana mereka pada asasnya telah menolak Islam. Dilantik oleh pemerintah,

25 Ibn Qayyim al-Jawziyyah, al-Țuruq al-Hukmiyyah (Qāhirah: Matbaah al-Madani, t.t.), 350 .

26 Ibrahim Dasuki al-Shahawi, al-Hisbah fì al-Islām (Qāhirah: Maktabah Dār al'Urubah, 1962), 123. 
dilantik oleh pemerintah bagi menjalankan kerja hisbah tetapi jika tanpa lantikan pemerintah ia boleh melakukan kerja hisbah atas dasar sukarela. ${ }^{27}$

Beliau perlulah berilmu, kerana tanpa ilmu dia tidak akan dapat melaksanakan tugasnya dengan baik. Seseorang muhtasib dikendaki mengetahui ilmu-ilmu tertentu bagi bidang yang khusus bergantung bentuk tugas mereka. Berkemampuan, dari pelbagai aspek, seperti kesihatan tubuh badan. Syarat ini boleh diperluaskan untuk mencakupi pelbagai aspek yang diperlukan dalam melaksanakan tugas hisbah yang meliputi bidang yang luas. Seterusnya, seseorang muhtasib perlu bersifat adil, kerana tanpa sifat ini seseorang itu tidak akan dapat melaksanakan tugasnya dengan baik, walau bagaimanapun ada juga ulama tidak mensyaratkannya.

Kesimpulannya, Wilāyah al-Hisbah merupakan suatu mekanisme penting dalam pemerintahan Islam. Kewujudannya mampu memberi impak yang berkesan terutama dalam muamalah sesama manusia. Perkara-perkara yang dilarang oleh Allah SWT hendaklah dicegah daripada berlaku di kalangan masyarakat. Tidak dilupakan juga hak Allah SWT sebagai pembuat segala hukum yang telah ditetapkan.

\section{Syura}

Sesungguhnya syura mempunyai suatu nilai yang penting terutama dalam pembentukan jemaah ke arah menyatu padukan masyarakat. Selain itu, syura juga merupakan elemen yang penting di dalam sesebuah negara Islam. Ini kerana ia merupakan lambang kepada negara Islam. Di samping itu, ia juga telah di perintahkan oleh Allah SWT di dalam al-Quran dan sunnah nabi. Terdapat juga sebahagian para ilmuan yang mengatakan bahawa syura dan demokrasi itu sama tetapi sebaliknya berlaku kerana keduanya berbeza walaupun terdapat sedikit persamaan.

Menurut bahasa, syura memiliki dua pengertian, iaitu menampakkan dan memaparkan sesuatu atau mengambil sesuatu. ${ }^{28}$ Dari segi istilah ia merujuk kepada hakim atau qadi atau orang-orang yang mukallaf dalam perkara yang tidak disebut hukumnya dalam nas al-Quran dan sunnah Nabi saw atau persepakatan ulama (ijmak ulama) berdasarkan dalil-dalil ijtihädiyah daripada

27 Mahmud Helmi, Niẓām al-Ḥukm al-Islāmī (Qāhirah: Dār al-Fikr, 1973), 344345.

28 Ibn Zakariyā, Aḥmad Ibn Fāris, Mu'jam Maqayis al-Lughah, vol.1 (t.t.p.: Matba'ah Muștafā al-Bābī al-Ḥalābī, 1972), 226. 
ulama yang mujtahid. Syura ini mesti berlaku apabila berlaku pandangan atau perbincangan secara jemaah bukan berlaku secara perseorangan. ${ }^{29}$

Syura telah lama diamalkan oleh para nabi dan rasul dikuti amalannya hingga ke hari ini. Amalan syura ini boleh dilihat berdasarkan peristiwa antara Nabi Ibrahim dan anaknya Ismail. Peristiwa ini dinyatakan dalam al-Quran:

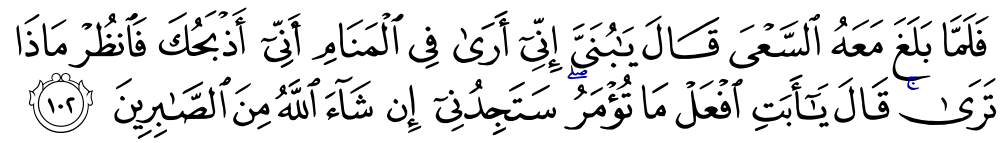

"Maka ketika anaknya itu sampai (ke peringkat umur yang membolehkan dia) berusaha bersama-sama dengannya, Nabi Ibrahim berkata: "Wahai anak kesayanganku! Sesungguhnya Aku melihat dalam mimpi bahawa aku akan menyembelihmu; maka fikirkanlah apa pendapatmu?" Anaknya menjawab: "Wahai ayah, jalankanlah apa Yyang diperintahkan kepadamu; insya Allah SWT, ayah akan mendapati daku dari orang-orang yang sabar."

(Surah al-Ṣāffăt, 37: 102)

Berdasarkan ayat di atas, telah berlaku dialog antara Nabi Ibrahim dengan anaknya Ismail tentang mimpinya yang ingin menyembelih anaknya. Dialog yang berlaku ini merupakan satu bentuk musyawarah. Ini kerana Nabi Ibrahim terlebih dahulu meminta pandangan anaknya tentang mimpi yang dialaminya tanpa terus melakukan penyembelihan.

Di antara dalil terkuat berkaitan dengan syura adalah dalam firman Allah SWT:

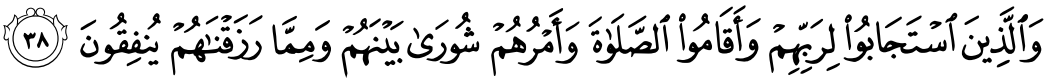

"Dan juga (lebih baik dan lebih kekal bagi) orang-orang yang menyahut dan menyambut perintah Tuhannya serta mendirikan sembahyang dengan sempurna; dan urusan mereka dijalankan secara bermesyuarat sesama mereka; dan mereka pula mendermakan sebahagian dari apa yang kami beri kepadanya."

(Surah al-Syūrā, 42: 38)

29 Al-Sallabi, 'Alī Muhammad Muhammad, al-Shūrāa Farị̄ah al-Islāmiyyah (Dimashq: Dār Ibn Kathīr, 2010), 109. 
Ayat di atas jelas menunjukkan bahawa musyawarah merupakan salah satu tuntutan dalam kehidupan orang Islam. Melalui musyawarah ini, ahliahlinya dapat mengutarakan pelbagai pandangan yang dapat memberi manfaat dan faedah yang besar kepada umat Islam. Sikap saling menerima pandangan antara satu sama lain amat ditekankan dalam musyawarah supaya tidak berlaku pertelingkahan yang boleh memudaratkan kepada ahli syura khususnya dan masyarakat amnya.

Rasulullah SAW telah memberi suatu jalan kepada umatnya untuk saling berbincang mengenai sesuatu perkara yang besar dan penting terutama melibatkan hak dan kepentingan negara. Syura amat memainkan peranan penting supaya pemimpin tidak memutuskan suatu keputusan yang boleh mendatangkan kemudaratan kepada rakyat amnya dan negara khususnya. Ini adalah mekanisme yang perlu dipertingkatkan lagi kegunaannya pada masa akan datang.

\section{Fatwa}

Pada masa kini, fatwa dilihat begitu penting dalam menyelesaikan permasalahan atau isu yang timbul di kalangan umat Islam. Sesuatu isu yang timbul itu berlaku adalah rentetan daripada perubahan zaman yang semakin maju. Ianya adalah amat berbeza sekali jika dibandingkan dengan situasi zaman dahulu seperti zaman kehidupan junjungan besar yang mulia iaitu Rasulullah SAW. Pada zaman tersebut isu-isu yang menjadi kesamaran bagi umat Islam agak sedikit. Sekiranya sesuatu isu itu timbul, umat Islam akan terus merujuk perkara tersebut kepada Baginda yang merupakan satu-satunya sumber rujukan utama dalam segala permasalahan.

Fatwa yang benar dan tepat dapat menjamin perlaksanaan atau perjalanan syariat Islam. Justeru itu, sesiapa yang ingin mengeluarkan fatwa tidak lari dari kaedah dan sumber utama iaitu al-Quran dan al-Sunnah. Para ulama perlu memainkan peranan yang penting terutama dalam mengeluarkan sesuatu hukum selain memberi tunjuk ajar dan bimbingan kepada golongan yang tidak tahu tentang sesuatu perkara.

Menurut Ibn Manẓūr, fatwa adalah perkataan yang bermaksud suatu perbuatan yang dilakukan oleh mufti mengenai sesuatu hukum atau suatu keputusan hukum yang dikeluarkan oleh faqih. ${ }^{30}$ Wahbah al-Zuhaylī mengatakan bahawa fatwa adalah sebagai jawapan yang dibuat oleh mufti

30 Ibn Manẓūr, Lisān al- 'Arab, vol. 15 (Beirūt: Dār al-Beirūt, 1956), 147-148. 
pada perkara yang berlaku apabila diajukan soalan kepadanya. ${ }^{31}$ Berdasarkan kepada perkara tersebut, terdapat dua firman Allah SWT yang berkaitan dengan fatwa iaitu:

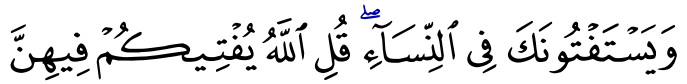

"Dan mereka minta fatwa kepadamu tentang wanita, katakanlah Allah SWT memberi fatwa kepadamu tentang mereka.."

(Surah al-Nisā', 4: 127)

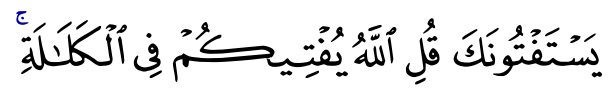

"Mereka meminta fatwa kepadamu, katakanlah Allah SWT memberi fatwa tentang kalalah..”

(Surah al-Nisā', 4: 176)

Memberi fatwa adalah fardu kifayah dalam Islam. Oleh itu, bagi mereka yang berpengetahuan luas dalam sesuatu bidang sewajarnya menjelaskan pertanyaan jika di sana tidak terdapat orang yang berpengetahuan selain darinya di wilayah tersebut. Fatwa sangat penting dalam kehidupan ini dan kewujudan fatwa membolehkan perlaksanaan hukum-hukum syarak ditegakkan berlandaskan kaedah-kaedah Syariah.

Garis perbezaan antara memberi fatwa dan menghukum adalah sekiranya seseorang itu dihukum maka dia dikehendaki menerima hukuman tersebut. Adapun dari segi fatwa pula ialah memberi penjelasan tentang hukum syarak yang berlaku dalam perkara yang diminta fatwa dalam bentuk umum dan ianya tidak diwajibkan. Dari segi perbezaan tersebut ternyata lingkungan memberi fatwa lebih luas dari bidang kuasa menghakim. Memberi fatwa adalah harus baik dari seorang hamba, orang merdeka, wanita atau lelaki bahkan mungkin dari seorang yang buta jika ia berpengetahuan berhubung dengan fatwa. Sifat yang demikian berbeza dengan penghakiman. ${ }^{32}$

Antara contoh fatwa yang berlaku ketika zaman pemerintahan 'Umar alKhattab, beliau telah memutuskan bahawa talak tiga yang diucapkan oleh suami dalam satu majlis maka dikira sebagai talak tiga. Ini bertentangan dengan keputusan yang telah dibuat ketika zaman Rasulullah SAW iaitu talak tiga yang diucapkan oleh suami dalam satu majlis dikira talak satu. Saidina 'Umar al-Khattab menetapkan perkara tersebut disebabkan oleh para suami

31 Wahbah al-Zuhaylī, Ușūl al-Fiqh al-Islāmī (Damsyik: Dār al-Fikri, 1976), 1156.

32 Ahmad Shalaby, Tārīkh Niz̄ām al-Qaḍa ’iyyah fí al-Islām, 245. 
yang sering memandang ringan akan talak tersebut dan mencegahnya daripada berleluasa.

Tidak boleh bagi seseorang mufti membetulkan dirinya atau keluarganya dengan mengajukan fatwa yang tertentu bagi mereka dan memberikan fatwa dalam bentuk sifat yang lain kepada golongan yang lain. Tindakan ini bererti merosakkan nilai keadilan kecuali terdapat sifat-sifat khusus bagi berlaku demikian. Telah dinyatakan bahawa persoalan ibadat tidak termasuk dalam lingkungan kehakiman dan ianya termasuk dalam fatwa.

Kesimpulannya, fatwa merupakan suatu bentuk penjelasan tentang sesuatu hukum yang berlaku. Fatwa ini bukanlah perkara wajib yang perlu dipatuhi. Namun begitu, ia boleh menjadi suatu panduan kepada pemerintah agar tidak melakukan perkara yang sia-sia dan tidak berfaedah. Para mufti boleh memberi teguran dan nasihat kepada pemerintah sekiranya keputusan yang dikeluarkan itu tidak memberi keuntungan dan manfaat kepada rakyat.

\section{Wilāyah al-Maz̄ālim}

Al-Mazāilim berasal daripada perkataan Arab yang bermaksud "nama bagi sesuatu yang diambil oleh orang yang menganiaya seseorang". Manakala dari segi istilah ulama fiqh ia adalah satu jawatan kehakiman yang bidang kuasanya lebih luas daripada bidang kuasa hakim biasa dalam institusi kehakiman. Dalam hal ini, Ibn Khaldun menyebutnya sebagai "gabungan antara kewibawaan pemerintahan dan keadilan hakim". ${ }^{33}$

Mahkamah al-Mazālim secara umumnya lebih menyerupai sistem mahkamah pentadbiran sekarang. Pada asalnya ia ditubuhkan untuk membicarakan amalan gabenor, pemerintah dan pegawai kerajaan yang tidak dapat dibicarakan oleh qadi biasa dan kadang-kadang dibicarakan oleh pemerintah terhadap pertikaian yang tidak dapat diputuskan oleh pengadilan atau terhadap hukum yang tidak dapat diyakini keadilannya oleh pihak yang bertikai. Sistem Mahkamah al-Mazālim ini sekali gus meliputi bidang pengadilan dan pelaksanaan. ${ }^{34}$

Al-Mawardī telah menjelaskan bahawa Wilāyah al-Maz̄ālim ini bertindak memaksa orang berlaku zalim agar meninggalkan kezaliman dan menerima keinsafan dengan cara menakutkan merekan dan mencegah orang yang bertikai tidak meneruskan pertikaian dan persengketaan. Malahan menerima

33 'Abd al-Karīm Zaydān, Niẓām al-Qaḍ̄' fì al-Syarī'ah al-Islāmiyyah, 253.

34 Wahbah al-Zuhaylī, al-Figh wa Adillatuhu, vol. 8 (Damsyik: Dār al-Fikr, 1984), 6252 . 
penyelesaian dan perdamaian melalui kehebatan kuasa yang menggerunkan. Orang yang bertindak melaksanakan tugas ini hendaklah memenuhi syaratsyarat tertentu iaitu mempunyai kuasa yang berkesan, perintah yang dilaksanakan, kehebatan yang menggerunkan, mempunyai kehormatan diri, kurang bersifat tamak dan warak kerana untuk melaksanakan tugas Walī alMazālim ia memerlukan kekuatan sebagai pelindung dan berhati-hati sebagai seorang qadi. Kedua-dua sifat ini hendaklah ada padanya. Ini bermakna ia hendaklah memiliki kemampuan yang istimewa dengan itu segala perintahnya akan dipatuhi dan dilaksanakan oleh pihak-pihak yang terlibat. ${ }^{35}$

Wilāyah al-Mazālim atau dikenali juga dengan nama Qaḍ̄' al-Mażālim, Diwān al-Maẓālim dan Șạhị al-Mazālim telah lama dikenali dengan kewujudannya sejak zaman pemerintahan raja Parsi sebelum kedatangan Islam lagi. Mereka menganggap peranan Wilāyah al-Maẓālim tidak terikat dengan prosedur mahkamah biasa, Wilāyah al-Maz̄ālim merupakan mahkamah diraja yang diwujudkan oleh raja-raja Parsi atas keperluan keadilan dan undangundang. Raja Parsi yang pertama menubuhkan mahkamah ini ialah Kiyumaz. Baginda mendapati banyak berlaku kejahatan dan jenayah yang tidak tercegah di kalangan orang ramai. ${ }^{36}$

Semasa perbicaraan, para pembesar dikumpulkan dan dikehendaki memberikan penerangan dan pandangan, tetapi kuasa pemutus yang mutlak di tangan raja yang akan menetapkan hari-hari tertentu yang baginda akan menerima aduan rakyatnya. Pada hari tersebut rakyat yang merasa dizalimi ini akan bebas mengadukan kezaliman yang dialaminya kepada raja. Orang Arab jahiliyyah telah terpengaruh dengan sistem ini kerana ia amat penting untuk menegakkan keadilan, mencegah kezaliman dan menginsafkan orang-orang yang zalim. ${ }^{37}$

Di Madinah, Rasulullah SAW sendiri telah mengetuai institusi Wilāyah al-Mazālim sesuai dengan tugas Baginda sebagai ketua negara, ketua pemerintahan dan pentadbiran negara Islam pertama di Madinah. Antara kes kezaliman yang pernah diselesaikan oleh Baginda ialah pertelingkahan yang berlaku antara Zubayr al-Awwam dengan seorang lelaki Anșar yang melibatkan pembahagian air yang dikuasai oleh Zubayr yang enggan mengalirkan baki airnya ke kebun lelaki Ansar yang merupakan jirannya. Rasulullah SAW telah menerima aduan tersebut telah memerintahkan Zubayr supaya mengalirkan air tersebut ke kebun jirannya setelah kebunnya sendiri cukup untuk menerima

35 Al-Mawardī, Abī Ḥasan 'Alī, al-Ahkēom Sulțāniyyah wa Wilāyah al-Dìniyyah, 97.

36 Muḥammad Salam Madkur, al-Qad̄à' fì al-Islām (Mesir: Dār al-Nahdah, 1964), 141.

37 Muḥammad Salam Madkur, al-Qaḍā'fí al-Islām, 141. 
bekalan air. Dalam riwayat tersebut, didapati Zubayr merupakan seorang yang berpengaruh dan tambahan pula mempunyai hubungan kekeluargaan dengan Rasulullah SAW. ${ }^{38}$

Dari segi peranannya pula, ia merupakan satu institusi yang mempunyai peranan seperti menegakkan keadilan, menghapuskan kezaliman dan berusaha bagi memastikan bahawa tidak ada berlaku penyalahgunaan kuasa oleh golongan pemerintah dan mereka yang berpengaruh. Institusi ini lebih kuat pengaruhnya daripada institusi kehakiman, lebih mendalam kesan tindakannya dan lebih luas bidang kuasanya. Dalam melaksanakan peranannya, institusi ini tidak terikat dengan prosedur biasa yang lazimnya perlu diikuti dan dipatuhi sebagaimana yang dilalui oleh institusi kehakiman. Pengendalian kes di Wilāyah al-Mazālim ini lebih bebas dan tidak terikat dengan peraturan yang ketat seperti yang dihadapi oleh institusi kehakiman. Dalam proses kehakiman, ada kalanya keputusan mahkamah tidak dapat dilaksanakan walaupun menurut hukum syarak ia wajib dilaksanakan. Ini kerana terdapat halangan oleh golongan yang berpengaruh.

Oleh sebab itu, keadilan tidak dapat dilaksanakan dan ditegakkan, akan tetapi dengan adanya Wilāyah al-Mazālim ini yang mempunyai kuasa dan pengaruhnya maka keadilan akan dapat ditegakkan dan hukuman yang telah diputuskan oleh mahkamah dapat dilaksanakan. Inilah sebab utama yang meletakkan Wilāyah al-Maz̄ālim ini lebih tinggi kedudukannya berbanding institusi kehakiman. Antara keistimewaan yang ada pada Wilāyah al-Mazāalim ialah ia boleh bertindak demi menegakkan keadilan dan menghapuskan kezaliman dengan menggunakan kekerasan dan hisbah yang melahirkan kegerunan kepada orang bersikap zalim.

Terdapat beberapa bidang kuasa yang yang dikendalikan oleh Wilāyah alMazālim, sesetengahnya bersifat penasihat bagi pengawasan pelaksana hukumhukum syarak dan sesetengahnya bersifat pentadbiran bagi pengawasan pekerjaan pegawai kerja sekalipun tanpa aduan daripada orang ramai dan sebahagiannya bersifat pengadilan bagi membicarakan pertikaian antara pemerintah dengan rakyat. Secara terperincinya antara bidang kuasa Wilāyah al-Maz̄āim ialah: ${ }^{39}$

1. Membicarakan kes penganiayaan yang dilakukan oleh gabenor terhadap rakyat dan kekerasan kelakuannya terhadap mereka.

\footnotetext{
38 'Atiyyah, Mușțafā Musyrifah, al-Qaḍà' fì al-Islām (Qāhirah: Sharikah al-Sharq al-Awsat, 1966), 18.

39 Wahbah al-Zuhaylī, al-Fiqh wa Adillatuhu, vol. 8 (Damsyik: Dār al-Fikr, 1984), 6254-6256.
} 
2. Membicarakan kes penyelewengan pekerja yang berkait dengan kewangan. Dalam kes ini dirujuk kepada undang-undang yang adil yang terdapat di dalam kitab-kitab para ulama. Mereka hendaklah dihukum berdasarkannya. Lebihan wang dari yang sepatutnya diperolehi hendaklah diteliti. Sekiranya telah diserahkan kepada Baitulmal, arahan supaya dikembalikan hendaklah dilakukan. Sekiranya dia mengambil untuk kepentingan dirinya, maka dia hendaklah diminta supaya mengembalikannya kepada pemilik asal.

3. Meneliti kerja pendaftar senarai-senarai tentera kerana mereka diamanahkan oleh orang-orang Islam untuk mencatatkan kewangan yang dibahagikan kepada orang yang berhak dan memungut wang.

Ketiga-tiga bahagian tersebut tidak memerlukan Ketua Mahkamah alMazālim untuk memaklumkan kepada orang yang mendakwa.

4. Membicarakan aduan pegawai kerja dan tentera dari segi kekurangan sara hidup mereka atau kelewatan pemberian sara hidup itu.

5. Memulangkan barang rampasan tanpa hak. Perkara ini terbahagi kepada dua iaitu:

a. Rampasan tanpa hak yang dilakukan oleh pihak pemerintah atau gabenor daripada tuan punya sama ada diambil untuk negara atau untuk diri mereka sendiri secara kezaliman. Ketua Mahkamah alMazālim hendaklah memerintahkan supaya dikembalikan kepada tuan punya jika dia mengetahuinya semasa menjalankan pemeriksaan ke atas gabenor sekalipun sebelum dibuat aduan kepadanya. Jika dia tidak mengetahui maka terhenti di atas perbicaraannya apabila dibuat aduan oleh tuan punya.

b. Rampasan yang dilakukan oleh pihak yang kuat daripada kalangan orang menjalankan tugas kerajaan, yang dilakukan kepada tuan punya dengan kekerasan dan paksaan. Kes ini dibicarakan apabila dibuat aduan oleh tuan punya.

Tidak boleh diambil daripada tangan perampas kecuali dengan empat perkara iaitu pengakuan daripada perampas atau pengetahuan Ketua Mahkamah al-Mażālim mengenai perkara itu, atau ada keterangan yang membuktikan rampasan itu, atau ada berita yang menafikan rampasan tersebut disengajakan dan tidak terdapat keraguan mengenainya.

6. Mengendalikan urusan wakaf. Ini terbahagi kepada dua iaitu:

a. Wakaf am untuk kepentingan awam seperti masjid, sekolah dan seumpamanya. Perkara ini menjadi tugasnya sekalipun tiada aduan supaya dapat dibahagikan hasilnya yang terdapat dalam simpanannya 
dan melaksanakan syarat-syarat pewakaf apabila diketahui melalui salah satu cara iaitu sama ada daripada catatan pegawai yang menjaga hukum, senarai kerajaan atau daripada catatan lama yang lama yang memperkuatkan andaian kesahihannya, sekalipun tiada kesaksian daripada saksi.

b. Wakaf khas iaitu wakaf bagi orang-orang yang tertentu. Dalam kes ini ia tidak menjalankan perbicaraan kecuali ada aduan daripada orang yang berhak dan tidak boleh menghukum dengannya kecuali dengan pembuktian biasa yang ditetapkan oleh syarak.

7. Melaksanakan hukuman mahkamah yang tidak dapat dilaksanakan lantaran kebebasan orang yang dijatuhkan hukuman dan kekuatan kuasanya atau kerana sifatnya yang tinggi dan besar bahayanya.

8. Membicarakan kes yang tidak dapat dilakukan oleh pengendali hisbah dalam kes yang tidak ada kaitan dengan kepentingan awam seperti kemungkaran yang diiklankan tetapi mereka (pengendali hisbah) tidak mampu menghapuskannya, keganasan di jalan-jalan yang mereka tidak mampu untuk mengembalikannya.

9. Melakukan ibadah-ibadah yang zahir seperti sembahyang Jumaat, sembahyang hari raya, haji dan jihad tanpa kelalaian dan cacat syaratsyaratnya kerana hak Allah SWT lebih awla disempurnakan dan semua kewajipannya lebih berhak ditunaikan.

10. Membicarakan kes di antara dua pihak yang bergaduh dan menjatuhkan hukuman ke atas kedua-dua pihak yang bertikai. Oleh itu penelitian terhadap kes mereka tidak boleh keluar daripada tuntutan kebenaran dan hak setiap mereka. Hukuman yang dijatuhkan kepada mereka pula hendaklah hukuman yang sama yang dijatuhkan oleh pemerintah dan para qadi.

Ini menunjukkan bahawa qadi di Wilāyah al-Maẓālim mempunyai bidang kuasa ke atas qadi apabila kedua-dua pihak yang bertikai membawa kes kepadanya.

Mahkamah al-Mazālim mempunyai bidang kuasa yang luas untuk mencegah kezaliman khususnya yang dilakukan oleh para pegawai, golongan berpengaruh dan bangsawan. Ini bermakna, Walì al-Mazālim yang mengetuai institusi ini hendaklah seseorang yang mempunyai sifat warak, alim, bijaksana, adil, mempunyai haibah yang dihormati dan kekuasaan yang disegani dan merupakan rujukan terakhir rakyat untuk mendapatkan keadilan dan mencegah kezaliman. Jika diperhatikan dengan teliti ternyata jawatan Wali al-Mazālim ini sentiasa disandang oleh khalifah atau pemerintah yang mempunyai kuasa atau orang yang dilantik oleh khalifah untuk memegang jawatan tersebut. 
Untuk memastikan Mahkamah al-Mazālim dapat memainkan peranannya seperti yang dikehendaki oleh Islam, maka ia memerlukan pegawai serta petugas yang berkebolehan. Para ulama berpendapat keanggotaan atau kakitangan Mahkamah al-Maz̄ālim terdiri daripada: ${ }^{40}$

1. Hakim atau Walì al-Mazālim yang berwibawa, mampu untuk memberikan hak kepada yang berhak, mencegah kezaliman dan menegakkan keadilan.

2. Fuqaha, agar hakim boleh merujuk kepada mereka, dalam perkara yang memerlukan pandangan dan nasihat mereka. Dengan itu setiap keputusan dan hukuman akan bersesuaian dengan kehendak syarak.

3. Saksi dalam kes yang memerlukan keterangan mereka kerana tanpa keterangan, hakim atau Walì al-Mazāilim tidak akan dapat menjatuhkan hukuman dengan tepat.

4. Pencatat, Mahkamah al-Mazālim memerlukan pencatat keterangan dan perbicaraan. Dengan adanya catatan yang tepat maka akan dapat memudahkan hakim meneliti semula segala keterangan dan hujah sebelum menjatuhkan hukuman.

5. Pengawal dan pembantu agar perjalanan perbicaraan berjalan lancar tanpa gangguan, keamanan dapat dipastikan, pihak yang terlibat akan dilindungi dan pihak yang merasa dirinya bersalah tidak akan dapat melarikan dirinya.

Ketika zaman Khalifah 'Umar, beliau sendiri yang mengetuai Wilāyah al-Maz̄ālim dalam membicarakan kes-kes kezaliman. Ketika musim haji, pegawai-pegawai kerajaan dipanggil untuk disoal siasat tentang tugas yang mereka jalankan dan sebab kezaliman itu berlaku. Perbicaraan ini dilakukan di hadapan orang ramai. Tujuan utama perbicaraan ini dilakukan adalah untuk mengembalikan hak orang yang berhak, mengekalkan keadilan dan menghindarkan para pegawai daripada melakukan kezaliman. ${ }^{41}$

Kesimpulannya, Wilāyah al-Mazālim ini memainkan peranan yang cukup besar dalam pemerintahan dan pentadbiran dalam Islam. Kekuasaannya amat penting dalam menegakkan keadilan terutama kepada golongan yang berpengaruh dan berkuasa. Mekanisme ini amat ditekankan supaya kezaliman dapat dicegah dan orang yang tidak mempunyai pengaruh berasa selamat untuk mengemukakan aduan. Kesemua prinsip yang telah dikemukakan ini sebagai penguat kepada elemen-elemen yang telah dibincangkan sebelum ini iaitu Iman, Islam dan Ihsan.

40 Muhammad Salam Madkur, al-Qad̄à'fì al-Islām, 146-147.

41 Mahmud Helmi, Niẓām al-Ḥukm fì al-Islām (Qāhirah: Dār al-Fikr al-'Arabī, 1973), 338. 


\section{APLIKASI SEMAK DAN IMBANG DALAM SISTEM KEHAKIMAN ISLAM DI MALAYSIA}

Islam amat menitikberatkan dan mengiktiraf kebebasan kehakiman bagi mencapai keadilan kepada semua pihak-pihak yang menuntut. Bagi memastikan kebebasan tersebut, terdapat beberapa mekanisme yang diguna pakai iaitu pelantikan hakim, kod etika hakim, rayuan, semakan kehakiman, mahkamah terbuka dan arahan amalan.

\section{Pelantikan Hakim}

Hakim adalah berfungsi sebagai penyeru kepada kebaikan dan mencegah kemungkaran serta kezaliman di dalam sesebuah masyarakat. Ia juga merupakan salah satu daripada tanggungjawab atau kewajipan kepada umat Islam yang wujud di bawah pemerintahan sistem khilafah. Apabila melihat kepada peranan penting jawatan hakim dalam menegakkan keadilan kepada masyarakat maka pelantikan jawatan tersebut perlu melalui beberapa kaedah tertentu. Keadah-kaedah ini merupakan satu proses semak dan imbang supaya hakim yang dilantik itu benar-benar layak menjadi seorang hakim.

Di Malaysia, seseorang yang hendak menjadi hakim perlu memenuhi beberapa kriteria seperti yang telah diperuntukkan dalam Enakmen/Akta Pentadbiran Negeri-negeri. Untuk menjawat jawatan Ketua Hakim Syarie di Wilayah Persekutuan, lantikan dibuat oleh Yang di-Pertuan Agong atas nasihat Menteri selepas berunding dengan Majlis. Hakim itu mestilah seorang warganegara dan mempunyai pengalaman hampir 10 tahun memegang jawatan Hakim Mahkamah Tinggi atau Pendaftar atau Pendakwa atau salah satu dari jawatan tersebut serta seorang yang arif dalam hukum syarak. Hukum syarak di sini bermaksud Undang-undang Islam mengikut mana-mana Mazhab yang diiktiraf. $^{42}$

\section{Kod Etika Hakim}

Dalam Islam, ia dikenali sebagai adab qadi. Adab qadi membawa maksud perkara-perkara yang dilazimkan oleh syarak kepada seseorang qadi dalam melaksanakan tugasnya berlandaskan keadilan, menolak kezaliman, meninggalkan kecenderungan nafsu, memelihara hukum syarak dan mengamalkan segala yang ditetapkannya. Oleh itu, adab qadi merupakan

42 Seksyen 41, Akta Pentadbiran Undang-undang Islam (Wilayah-Wilayah Persekutuan) 1993. 
satu etika yang perlu dipatuhi oleh setiap qadi supaya segala keputusan atau tindakan yang dilakukan tidak mendatangkan kezaliman pada mana-mana pihak yang bertikai.

Di Malaysia, satu kod etika hakim telah diwartakan bagi mengawal para hakim supaya tindakan atau keputusan yang dilakukan tidak mendatangkan kezaliman pada mana-mana pihak yang bertikai. Para hakim perlu ingat bahawa tugas sebagai seorang hakim besar bebanannya. Maka para hakim perlu sentiasa berhati-hati terutama ketika berada di luar mahkamah. Mereka tidak boleh mendedahkan diri mereka secara terbuka ketika bergaul dengan orang ramai. Ini kerana ia boleh menimbulkan syak tentang keupayaannya untuk berlaku adil ketika perbicaraan di jalankan. Selain itu, perlu diingat bahawa para hakim tidak boleh menggunakan kedudukannya sebagai seorang hakim untuk mendapatkan feadah untuk dirinya.

Selain itu, para hakim tidak boleh melengah-lengahkan kes yang dikendalikannya tanpa alasan yang munasabah. Mereka perlu menyegerakan menyelesaikan kes, memberi keputusan, menulis alasan penghakiman dan mematuhi arahan yang dikeluarkan oleh Ketua Hakim Syarie dari semasa ke semasa. Dalam masa yang sama, para hakim dikehendaki juga untuk mengisytiharkan harta kepada Ketua Hakim Syarie. Tujuannya supaya tidak berlaku penyelewengan terutamanya melibatkan rasuah.

\section{Rayuan dan Semakan Kehakiman}

Kedua-dua prosedur di atas merupakan satu peluang sama ada kepada para hakim mahupun pihak-pihak yang bertikai. Dalam hal ini, apabila mana-mana pihak tidak berpuas hati dengan keputusan yang telah dibuat, maka rayuan boleh dilakukan ke atas mahkamah yang lebih tinggi. Inilah yang dinamakan proses rayuan. Manakala bagi semakan kehakiman pula, ia berlaku apabila terdapat bantahan ketika prosiding dijalankan dan sebelum keputusan dikeluarkan.

Contoh prosedur kes rayuan adalah dalam kes Mohd. Ibrahim bin Mohd. Sharif lwn. Pendakwa Syarie Pulau Pinang. ${ }^{43}$ Perayu telah dituduh di Mahkamah Tinggi Syariah atas kesalahan berdua-duaan dengan seorang perempuan yang bukan isterinya atau mahramnya di sebuah bilik hotel. Pertanyaan dibuat sebanyak tiga kali sama ada perayu faham akan pertuduhan yang dibaca ke atasnya dan beliau telah mengaku bersalah. Maka hakim menjatuhkan hukuman penjara selama tiga bulan dan denda sebanyak RM

43 Mohd. Ibrahim bin Mohd. Sharif lwn. Pendakwa Syarie Pulau Pinang [1999] 2 SYA 8. 
2,000.00, sekiranya beliau gagal membayar denda, akan dipenjara selama enam bulan lagi. Perayu di sini tidak diwakili oleh peguam.

Tertuduh merayu ke Mahkamah Rayuan Syariah bukan sahaja terhadap hukuman tetapi juga terhadap sabitan. Di Mahkamah ini, tertuduh diwakili peguam. Seksyen 152(2) Enakmen Acara Jenayah Syariah (Negeri Pulau Pinang) 1996 memperuntukkan:-

“152. (2) Jika orang tertuduh mengaku salah dan disabitkan di atas akuan itu, dia tidak boleh merayu kecuali tentang kadar atau keesahan hukuman itu."

Seksyen ini dengan jelas menerangkan bahawa rayuan hanya boleh dibuat untuk untuk pengurangan kadar dan keesahan hukuman. Rayuan untuk sabitan hukum tidak dibenarkan. Perlu ditekankan bahawa seorang tertuduh yang mengaku salah tidak berhak untuk merayu terhadap sabitan. Tetapi, Mahkamah berhak untuk meneliti rekod rayuan, dan di mana patut dilakukan kerana terdapat kegagalan keadilan, mengenepikan sabitan berkenaan. Ini hak Mahkamah Rayuan, bukan hak Perayu (Tertuduh) dan, Mahkamah Rayuan melakukannya dengan memakai kuasa penyemakan.

Berdasarkan kepada kes ini, seseorang itu dibenarkan untuk membuat rayuan cuma perlu diingatkan kepada mana-mana pihak yang ingin membuat rayuan supaya tidak membuat rayuan untuk mengenepikan sabitan hukum. Hakim telah menjalankan tanggungjawabnya dengan baik sekali. Pertanyaan sebanyak tiga kali dibuat bagi memberi ruang kepada tertuduh untuk memahami tuduhan ke atasnya.

Manakala berkaitan dengan semakan kehakiman ada beberapa perkara yang perlu diberi perhatian. Ini bersesuaian dengan Arahan Amalan yang dikeluarkan iaitu:

Arahan Amalan No. 13 Tahun 2003

Peraturan Semakan Kes di Mahkamah Tinggi Syariah Atau

Di Mahkamah Rayuan Syariah

Saya ingin menarik perhatian Y.A.A. kepada keputusan Mesyuarat Arahan Amalan Mahkamah Syariah seluruh Malaysia Bil 4 Tahun 2003 pada 22-24hb Ogos 2003 bersamaan 24-26 Jamadilakhir 1424H di Shah Alam, Selangor telah bersetuju dan mengesahkan untuk menerima pakai arahan amalan berhubung dengan peraturan semakan kes di Mahkamah Tinggi Syariah atau di Mahkamah Rayuan Syariah hendaklah mengikut peraturan seperti berikut:- 
1. Permohonan semakan boleh dibuat ke atas kes mal atau jenayah sama ada kes yang dalam prosiding atau yang telah diputuskan ;

2. Permohonan semakan kes oleh pihak-pihak hendaklah dibuat melalui Notis Permohonan bersama dengan Affidavit kecuali permohonan oleh Hakim Syarie ;

3. Pihak-pihak yang menerima keputusan dan mempunyai hak merayu adalah tidak digalakkan memohon semakan.

Berdasarkan kepada kedua-dua proses ini, dapat dilihat secara jelas bahawa semak dan imbang memainkan peranan yang penting. Pihak-pihak yang tidak berpuas hati terhadap sesuatu keputusan boleh merayu kepada mahkamah yang lebih tinggi. Begitu juga para hakim boleh mengubah, meminda atau mengekalkan sesuatu keputusan yang telah dibuat oleh mahkamah yang lebih rendah. Sebagai contoh di Selangor, terdapat beberapa perkara yang menyentuh isu berkaitan pengawasan dan penyemakan dalam Enakmen Pentadbiran undang-undang. Enakmen ini selari dengan prinsin Islam yang membenarkan proses rayuan dan semakan kehakiman dilakukan.

\section{Mahkamah Terbuka}

Seksyen 119 Enakmen Tatacara Mal Mahkamah Syariah (Negeri Selangor) 2003 menerangkan berkaitan pendengaran dalam mahkamah iaitu:

"Kecuali sebagaimana yang diperuntukan selainnya dalam Enakmen (Selangor) Akta (Wilayah Persekutuan) ini atau mana-mana undang-undang bertulis lain, semua prosiding yang dimulakan dengan saman hendaklah didengar dan diputuskan di dalam Mahkamah terbuka dan semua prosiding yang dimulakan dengan permohonan hendaklah didengar dan diputuskan di dalam Kamar.”

Keterbukaan mahkamah ini akan membenarkan orang luar hadir ke mahkamah dan akan bertindak sebagai penyemak dan pengimbang supaya hakim yang membicarakan kes akan rasa diri dia diperhatikan dan rasa diri dia disemak. Tatacara ini memastikan berlakunya semakan dan keseimbangan supaya hakim yang ingin membuat keputusan akan memberikan keputusan yang adil kepada pihak-pihak yang bertikai. ${ }^{44}$

44 Mohd Naim Mokhtar (Pengarah, Bahagian Sokongan Keluarga, pada ketika itu), dalam temu bual bersama beliau, pada 16 Disember 2012. 
Kes-kes yang melibatkan kekeluargaan yang mempunyai aib-aib tertentu hendaklah dilindungi daripada tersebar kepada pihak luar. Imam Nawawi ada menyebut barang siapa yang menutup aib saudaranya Allah akan menutup aibnya pada hari kiamat. Terdapat hadis yang menyatakan kita perlu menutup aib orang tapi Seksyen 119 mengatakan perbicaraan itu di buat di mahkamah terbuka dan rasionalnya ia dibuat secara terbuka sebagai 'checks and balances'. Untuk mengimbangi keperluan hakim untuk menutup aib ianya hanya berlaku kalau mahkamah itu tidak terbuka. Jadi dalam hal ini lebih manfaat kepada mahkamah terbuka berbanding menutup aib. ${ }^{45}$

\section{Arahan Amalan}

Arahan Amalan merupakan arahan-arahan bercetak yang dikeluarkan oleh Ketua Pengarah/Ketua Hakim Syarie bagi tujuan penyelarasan pentadbiran kehakiman di Mahkamah Syariah seluruh Malaysia. Ini merupakan singkatan dalam pembinaan arahan amalan. Perkataan ini berasal daripada perkataan Inggeris iaitu "Practice Direction". Practice ialah amalan iatu prosedur yang berkaitan dengan pengendalian prosiding guaman yang sebenar dan tertakluk kepada peratuaran Kaedah Mahkamah Tinggi. Prosedur itu pula ialah langkah-langkah rasmi yang mesti dilakukan dalam sesuatu tindakan atau lain-lain prosiding guaman, sivil atau jenayah. Directory ialah panduan. Ia memperuntukkan dalam statut atau peraturan yang tidak mempunyai kuasa mandatori atau mustahak tetapi ia menjelaskan dengan terperinci cara sesuatu perkara itu sepatutnya dilaksanakan. ${ }^{46}$

Penggunaan Arahan Amalan ini sebenarnya tidak lari daripada kehendak peruntukan undang-undang seperti mana yang terdapat dalam Undang-Undang Keluarga Islam Negeri-Negeri:

“(2) Mengenai perkara amalan dan acara dalam perbicaraan hal ehwal suami isteri yang tidak diperuntukkan dengan nyata dalam Enakmen ini atau dalam apa-apa kaedah yang dibuat di bawah Enakmen ini atau dalam Enakmen Pentadbiran, Mahkamah boleh memakai apa-apa amalan dan acara yang difikirkannya wajar bagi mengelakkan ketidak adilan dan bagi menyelesaikan perkara-perkara yang dipersoalkan antara pihak-pihak."

\footnotetext{
45 Mohd Naim Mokhtar (Pengarah, Bahagian Sokongan Keluarga, pada ketika itu), dalam temu bual bersama beliau, pada 16 Disember 2012.

46 Mohd Naim Mokhtar (Pengarah, Bahagian Sokongan Keluarga, pada ketika itu), dalam temu bual bersama beliau, pada 16 Disember 2012.
} 
Untuk menjadikan Arahan Amalan yang dikeluarkan oleh Jabatan Kehakiman Syariah sah digunapakai oleh Mahkamah Syariah Negeri-Negeri, Ketua Hakim Syarie Negeri-Negeri hendaklah mengendoskan pemakaiannya ke seluruh Mahkamah Syariah di negeri tersebut yang dengan sendirinya menjadi seolah-olah Arahan Amalan negeri itu.

\section{KESIMPULAN}

Semak dan imbang merupakan satu amalan yang telah digunapakai sejak lama dahulu. Namun, dalam Islam istilah ini sedikit berbeza kerana prinsip semak dan imbang dalam Islam lebih luas penggunaannya. Prinsip Hudud Allah yang diperkenalkan lebih membawa kesan yang mendalam terhadap diri individu khususnya dan organisasi atau agensi amnya. Kewujudan prinsip ini mampu memandu manusia ke arah jalan yang benar dan keadilan mudah dicapai dan ditegakkan serta mampu mengimbangi dan mengawalselia setiap perbuatan manusia supaya tidak tersasar daripada landasan kebenaran.

Dari segi amalannya di Malaysia, bagi memastikan matlamat penubuhan mahkamah tercapai iaitu menegakkan keadilan, maka mahkamah perlu ada proses tertentu yang boleh mencapai keadilan dan mencegah kezaliman. Mekanisme yang diketengahkan ini mampu memberi impak dan kesan yang besar dalam badan kehakiman. Kes-kes yang dibicarakan akan diadili dengan seadilnya tanpa mengambil kira pangkat atau kedudukan seseorang.

Setiap kes yang dibicarakan akan diteliti dengan sebaiknya. Panduanpanduan dan manual kerja sebagai seorang hakim hendaklah difahami dengan jelas supaya tidak menjadi pertikaian pada masa akan datang. Setelah yakin dan memahami fakta sesuatu kes barulah hukuman dijatuhkan. Sebagai seorang hakim, perkara-perkara yang boleh menjejaskan kredibilitinya sebagai seorang hakim hendaklah dijauhkan.

\section{RUJUKAN}

'Abd al-Karīm Zaydān, Nizām al-Qad̄̄' fì al-Syarī'ah al-Islāmiyyah (Beirūt: Muassasah al-Risālah, 1995).

'Alī Muhammad Muhammad al-Sallabi, al-Shūrā Farīẹah al-Islāmiyyah (Dimasq: Dār Ibn Kathīr, 2010).

'Atiyyah Mușțafā Musyrifah, al-Qad̄à'fì al-Islām (Qāhirah: Sharikah al-Sharq al-Awsat, 1966).

Abdul Aziz Bari, Perlembagaan Malaysia Teori \& Praktis (Selangor: Arah Publications, 2008). 
Ab̄̄ Hasan al-Mawardī, al-Aḥām Sulțāniyyah wa Wilāyah al-Dīniyyah, (Beirūt: Dār al-Kutub 'Alamiyah, 1980).

Abu A'la al-Maududi, Islamic Law and Its Constitution (Lahore: Islamic Publication, 1980).

Aḥmad Muștafā al-Maraghī, Tafsīr al-Maraghī, vol. 1 (Beirūt: Dar al-Kutub 'Alamiyyah, 1974).

Aḥmad Shalaby, Tarikh Niz̄ām al-Qaḍā'iyyah fì al-Islām (Azhar: Dār al-Wafa' li al-Ṭaba'ah, 1981).

Daniel E. Branmen Jr \& Lawrence W. Baker, Checks and Balances: The Three Branches of the America Government (Detroit: Thomson/Gale, 2005).

David Wootton, 'Liberty, Metaphor, and Mechanism: Checks and Balances and the Origins of Modern Constitutionalism - Liberty and American Experience in the Eighteenth Century,' http://oll.libertyfund. org/?option=com_staticxt\&staticfile, akses 16 September 2011.

Encyclopedia America (Danbury: Sholastic Library Publishing, 2006).

Ibn Kathīr, Imam Jalil Hafiz al-Dīn Abū Fidā’ Ismā‘̄il, Tafsir Ibn Kathīr, vol. 1

(Qāhirah: Maktabah Qayyimah,1993).

Ibn Manẓūr, Lisān al- 'Arab vol. 15 (Beirūt: Dār al-Beirūt, 1956).

Ibn Qayyim al-Jawziyyah, al-Ṭuruq al-Hukmiyyah (Qāhirah: Matba'ah alMadani, t.t.).

Ibn Zakariyā Aḥmad Ibn Fāris, Mu’jam Maqayis al-Lughah, vol. 1 (t.tp: Matba'ah Mustafā al-Bābi al-Halābi, 1972).

Ibrahim Dasuki al-Shahawi, al-Hisbah fì al-Islām (Qāhirah: Maktabah Dār al-'Urubah, 1962).

K. Ramanatahan, Asas Sains Politik (Shah Alam: Fajar Bakti, 2003).

Mahmud Helmi, Niz̄ām al-Hukm al-Islāmī (Qāhirah: Dār al-Fikr, 1973).

Martin Kelley, 'Checks and Balances in the U.S. Government,' http:// americanhistory.about.com/od/usconstitution/a/checks_balances. htm14/12/12, akses 18 Jun 2013.

Muhammad Salam Madkur, al-Qaḍ̄' fì al-Islām (Mesir: Dār al-Nahdah, 1964).

Sayyid Qutb, Tafsīr fì Zilāl al-Qur'ān, vol. 1 (Beirūt: Dār Syuruk, 1972).

Sayyid Sābiq, 'Aqūdah al-Islāmiyyah (Qāhirah: al-Fatḥ al-I'lamī al-'Arabī, 2000).

Sheikh Ghazali Abd Rahman, 'Amalan-amalan Pentadbiran di Mahkamah Syariah,’ Jurnal Hukum XX/2 (2005). 
Tafsir Pimpinan al-Qur'an kepada Pengertian al-Qur'an, edisi ke-8 (Kuala Lumpur: Bahagian Hal Ehwal Islam, Jabatan Perdana Menteri, 1987).

The New Encyclopedia Britannica (International Copyright Union, 1995).

Wahbah al-Zuhaylī, Ușūl al-Fiqh al-Islāmī (Damsyik: Dār al-Fikri, 1976).

Wahbah al-Zuhaylī, al-Fiqh wa Adillatuhu, vol. 8 (Damsyik: Dār al-Fikr, 1984).

William Blackstone, Commentaries on the Laws of England, $15^{\text {th }}$ ed. (London: A. Strahan, 1809).

\section{Statut}

Akta Pentadbiran Undang-Undang Islam (Wilayah-Wilayah Persekutuan) 1993.

Enakmen Acara Jenayah Syariah (Negeri Pulau Pinang) 1996.

Enakmen Pentadbiran Agama Islam (Negeri Selangor) 2003.

Enakmen Tatacara Mal Mahkamah Syariah (Negeri Selangor) 2003.

\section{Kes}

Mohd. Ibrahim bin Mohd. Sharif lwn. Pendakwa Syarie Pulau Pinang [1999] 2 SYA 8.

\section{Temu bual}

Mohd Naim Mokhtar (Pengarah, Bahagian Sokongan Keluarga ketika itu), dalam temu bual bersama beliau, pada 16 Disember 2012. 
Jurnal Syariah, Jil. 24, Bil. 1 (2016) 59-92 